\title{
Tourism Development in the Dutch Wadden Area: Spatial-Temporal Characteristics and Monitoring Needs
}

\author{
Frans J. Sijtsma (Corresponding author) \\ University of Groningen, P.O. Box 800, 9700 AV, Groningen, The Netherlands \\ E-mail: f.j.sijtsma@rug.nl
}

Lourens Broersma

University of Groningen, P.O. Box 800, 9700 AV, Groningen, The Netherlands

E-mail: 1.broersma@rug.nl

Michiel N. Daams

University of Groningen, P.O. Box 800, 9700 AV, Groningen, The Netherlands

E-mail: M.N.Daams@rug.nl

Hendrik Hoekstra

University of Groningen, P.O. Box 800, 9700 AV, Groningen, The Netherlands

\section{Gelijn Werner}

Raad voor de Wadden, Leeuwarden, The Netherlands

Received: March 11, 2015 Accepted: March 25, 2015

doi:10.5296/emsd.v4i2.8561 URL: http://dx.doi.org/10.5296/emsd.v4i2.8561

\begin{abstract}
The paper presents a spatial and temporal analysis of tourism in the Dutch Wadden area and identifies policy dilemmas and monitoring needs. The analysis is temporal because historical, current and future aspects of tourism development are addressed; it is spatial because the spatial differentiaton of tourism within the Wadden area is examined. For the assessment of the historical and current situation focus is on visitor and employment data and especially the
\end{abstract}


relative degree of specialization of the local economy on tourism. For the future direction of tourism and possible investment options, the paper draws on surveyed views of 91 tourism entrepreneurs in the Wadden area. On the basis of this spatial and temporal analysis, the paper identifies policy dilemmas that differ substantially among the Wadden islands, the Waddensea, and the mainland Wadden coast. Drawing on this in depth empirical analysis the paper theoretically aims to enrich the Tourism Area Life Cycle (TALC) concept and the monitoring it implies. In response to the needs of monitoring sustainablilty, the paper argues for a broader yet still minimal extension of TALC. It argues for a four quadrant TALC - named TALC-4qin which four perspectives on tourism development are combined: market, ecology and nature, regional labor market and policy. The combination of monitoring visitor flows and market share, together with ecological quality, employment size and share, and the consensus on policy, is expected to refine the accuracy of the TALC concept and fuel its wider use in the search for sustainable tourism.

Keywords: Tourism development, Dutch Wadden area, Tourism Area Life Cycle (TALC), Visitors, Employment, World Heritage, Monitoring sustainability

\section{Introduction}

The Wadden area is an important tourism area of the Netherlands as well as a significant ecological area; the Waddensea part itself is a natural World Heritage property. ${ }^{1}$ Consequently tourism is an ever-present topic in recent Wadden area monitoring debates, evidenced by its key role in the recent Wadden Long-Term Ecosystem Research (WaLTER) initiative (Vugteveen, van Katwijk, Rouwette \& Hanssen, 2014). For the whole of the area, sustainable development and its monitoring, that is, the balancing and monitoring of ecological and socio-economic impacts, is a major issue (Butler, 1999; Enemark, 2005; Helbing, 1992; De Jong, 2007). Tourism is prominent in the search for sustainable development, since it may provide a balanced combination of both appreciation of the natural qualities of the area and the provision of income and jobs to the local community (Hernández \& León, 2007; Libosada, 2009). The present paper conducts a spatial-temporal analysis of tourism in the Dutch Wadden area, ${ }^{2}$ both with the aim of providing insight into its development and structure, and to identify major policy and monitoring challenges. The analysis is temporal because historical, current and future aspects of tourism employment are addressed; it is also spatial because the importance of spatial differentiation within the area is also shown (Hall \& Page, 2009). ${ }^{3}$ The central question of the work is: what are the spatial-temporal characteristics of tourism development in the Wadden area, and what does

\footnotetext{
${ }^{1}$ The Waddensea is one of the 193 natural World Heritage properties (As of January 2014). Most of the 981 World Heritage sites are cultural (http://whc.unesco.org).

${ }^{2}$ Various definitions exist for the Dutch Wadden area, some are more ecologically-based; others are more economically-based (Compare: Geoportaal Waddenzee at http://geonetwork.waddenzee.nl/). For our purpose here of a socio-economic and policy focus, the most fitting and widely used definition is that of 'the 18 municipalities bordering the Waddensea and which include water.' This definition is used throughout this paper.

${ }^{3}$ Several authors emphasize that spatial structure is essential to understanding the development of tourism and its potential [8], p. 6).
} 
this imply for the monitoring of the area?

To answer this question, a mixed method approach is applied (Brewer \& Hunter, 2006) and importantly, it is attempted to relate this approach to the Tourism Area Life Cycle (TALC). The TALC concept seems to be the most robust and widely-used conceptual and managerial framework in tourism worldwide (Butler, 2006a/b) and several authors, including Butler himself, have linked it to sustainability (Butler, 1999; Oreja Rodríguez, Parra-López \& Yanes-Estévez, 2008),. In the TALC concept the two axes, visitors and time, are central (Butler, 1980). Whereas, in this two-axis framework, five evolutionary stages for a tourism area can be defined: exploration, involvement, development, consolidation, and stagnation. For the historic development of the Wadden area, and staying close to the basics of TALC, we use a 100-year-long time series of visitors to the island of Terschelling in conjunction with newspaper articles of the same period in order to assess the stages in the life cycle of tourism at the Wadden islands.

Butler in 1980 realized the value of his framework because of the lessons it brought to those responsible for 'planning, developing, and managing tourist areas' (Butler, 1999, p11; Butler, 2006a/b). Policy is important when determining the future direction of a tourism area, and policy options differ markedly for areas which are, for instance, in the involvement stage of the life cycle or in areas in the stagnation stage. After stagnation, the evolution of an area may take a variety of routes, with rejuvenation and new growth on the upper extreme, and decline and diminishing numbers of visitors on the lower extreme. Hovinen (2002) and Getz (1992) have argued that some tourism areas in the later stages of development are better classified as being in a stage of maturity where 'elements of consolidation, stagnation, decline, and rejuvenation co-exist' (Getz, 1992, p.762); and the present paper will argue that this classification is useful for large parts of the Wadden area as well.

However, in order to be fully apprised of policy options, insight into visitor flows is not sufficient. Many authors, including Butler in his 1999 paper on sustainable tourism, have convincingly argued that that monitoring the environmental pressure of tourism is essential practice. If the TALC framework is to be used as a general framework for sustainable 'planning, developing, and managing tourist areas,' an extension is needed which at least includes key ecological variables (Hernández \& León, 2007; Claver-Cortés, Molina-Azorín, $\&$ Pereira-Moliner, 2007); this issue is taken as well-established from the literature. However, apart from the obviously necessary ecological variables, the analysis in this paper will demonstrate that the TALC framework may need, even further extension in its basic variables and perspectives (Farrell \& Twining-Ward, 2004). ${ }^{4}$ First, from a regional development perspective, the (potential) contribution of tourism to employment has been regarded as essential for decades (Deskins \& Seevers, 2011; Dissart \& Vollet, 2011; George Hughes, 1982; Polo, Ramos, Rey-Maquieira, Tugores \& Valle, 2008). Thus, apart from monitoring the number of visitors (or nights), and ecological variables, tourism employment should also be part of the tourism life cycle development. More specifically, the springboard for this analysis

\footnotetext{
${ }^{4}$ [16] argue that tourism research lacks a vision of tourism as a complex adaptive system. By extending the TALC framework this paper makes a step towards this aim.
} 
is that the relative degree of specialization in tourism - in terms of employment; the share of tourism in the regional economy -is fundamental to the understanding of policy options at different stages.

Second, for the determination of the future direction of a tourism area, the role of entrepreneurs is crucial (Russel \& Faulkner, 2004) and monitoring the degree of consensus on strategic issues may be pivotal for preventing decline (Hovinen, 2002). Ample attention is given to these issues in the following sections. In section 4.2 an enriched TALC- $4 \mathrm{q}$ framework is presented, which aims to be a more complete yet still succinct framework for 'planning, developing, and managing tourist areas.'

\section{Materials and methods}

\subsection{Historical Development}

A brief sketch of the long-term historical development of employment in tourism in the central Wadden island of Terschelling can be conveyed by relating it to the TALC concept. Terschelling has been selected due to the quantity of essential data on arrivals and employment for long time periods, as well as interpretative data, which allows for a thorough analysis of the various life cycle stages, including the early years. These more qualitative data, such as the onset of advertising, punctuated by periods of intensive infrastructure investments, were found in an analysis of 100 years of newspaper articles on Terschelling from the reputable regional newspaper, the Leeuwarder Courant (Hoekstra, 2009). ${ }^{5}$ Although only one of the islands in this historical part is under analysis, it is nevertheless fortunate that the island of Terschelling is typical in the development of all five Dutch Wadden islands and is therefore preferred as a single case study. Not only is it geographically the middle island, but it is also 'medium' sized in terms of area, employment, and vistors since it is situated in-between (together with Ameland) the two smallest islands Vlieland and Schiermonnikoog and the largest island of Texel. The historical employment data for different sectors of the economy (1909-2009) for Terschelling is derived from the municipality administration, while the data on passengers is taken from the ferry administration (Hoekstra, 1999).

\subsection{Current Situation and Recent Developments}

In order to depict the economic structure and articulate the importance of tourism in the Dutch Wadden area, various data sources are used. For the current situation of tourism a combination of data on visitor flows and employment is relevant, but availability differs per sub-region.

For visitor flows to the Wadden islands data on visitor nights from Statistics Netherlands, published yearly is applied. However, these data are not available for the coastal area; here, additional data for year 2006 from Toerdata Noord for the mainland coast municipalities in the provinces of Friesland and Groningen is analysed (Sijtsma, Werner \& Broersma, 2008).

\footnotetext{
5 This unique digital archive (http://www.archiefleeuwardercourant.nl/) covers the complete edition of the newspaper for over 250 years (!) including news articles and advertisements. We analysed the years January 1870-June 2009, focussing on the last 100 years (see [22] for detailed results).
} 
An estimation for the small remaining area, the North-Holland mainland coast, was carried out on the basis of the employment/visitor nights ratio for the Frisian and Groningen part of the mainland coast.

For employment data LISA data ${ }^{6}$ at the municipality level is used for 1996-2007; employment here covers all jobs, including small ones. Employment data in LISA are available for every Dutch municipality at a detailed sectoral level based on the Standard Industrial Categorization (Statistics Netherlands, 2014). None of these sectors add up to 'tourism or recreation', however. In order to identify 'tourism' jobs, two approaches may be used; first is to include the hotel and catering industry ('horeca') employment, an easily recognized so-called 'section" within the SBI 1993 scheme. This section comprises employment in hotels, cafés, restaurants, holiday parks, camp sites, etc. However, this section does not fully incorporate the spectrum of the tourism economy, as it does not include museums, harbours, swimming pools, bike rentals, diverse sporting activities, and so forth. Thus, the second approach, developed by the Netherlands Environmental Assessment Agency (PBL), comes to the fore. It measures broader 'leisure' employment. At the deepest level of the SBI-1993, PBL identifies 88 categories as 'leisure' activities, including all 11 of the hotel and catering industry (for details, see Sijtsma, Werner \& Broersma, 2008; appendix H). The focus in this paper is on the most inclusive measure, the 'leisure' employment, and is entitled 'tourism employment.' At the Wadden islands the share of the hotel and catering industry in total leisure employment ranges between $70 \%$ and $80 \%$. At the mainland coast the range is between $32 \%$ and $58 \% .^{7}$ In the present analysis the extent of tourism specialization is explored, i.e., the percentage of recreation and tourism employment in total employment.

\subsection{Future Direction of Tourism}

For the assessment of future developments a survey was conducted among 91 tourism entrepreneurs to investigate the future direction of tourism in the area and the degree of consensus therein. The entrepreneur survey was prepared by first conducting personal interviews among 21 key tourism stakeholders in the area (Sijtsma, Werner \& Broersma, 2008). In these interviews a wide array of future-oriented ideas for the Wadden sub-area were identified. This led to over 200 ideas, both for the islands and for the mainland coast, and to approximately 50 for the Waddensea. From this large and unordered set, an ordered set of 81 future policy and investment options was constructed.

On the basis of the ideas mentioned above, four scenarios were thereafter defined, using two 'axes': one of less or more identity change of the area; and one of more or fewer (but wealthier) visitors. The second is self-explanatory, but the first refers to an aspect often vital to Butler's rejuvenation: new activities and the reinvention of the tourism area (Baum, 1998). For instance, ideas put forward that were considered as identity changing, included Formula 1 racing in the mainland coastal area and large-scale attraction parks on the islands. Every

\footnotetext{
${ }^{6}$ www.lisa.nl

7 There may actually be a relation here with the degree of specialization and the size of the urban base: leisure employment will be equivalent tourism employment in highly specialized municipalities. In non-specialized municipalities a larger part of leisure (and 'horeca') will be provided for the local population.
} 


\section{Macrothink}

sub-area of the Wadden area, islands, sea and mainland coast were tested for the same four scenarios, although each has a slightly different name. The four scenarios are:

Scenario A - permitting possible change of area identity, more focus on few (wealthy) people

Scenario B - preserving area identity, more focus on few (wealthy) people

Scenario $\mathrm{C}$ - permitting possible change of area identity, focus on many people

Scenario D - preserving area identity, focus on many people

Investment options differed for every sub-area; each had a part comprised by the 81 options, with usually 6 or 7 policy options per scenario. In order to illustrate, for the islands the entrepreneurs could choose their preferred options from a list of 28. Under scenario B for the islands ('Sustainable Stay'), they could, for instance, choose 'ecotourism' or 'electrical cabs' (Sijtsma, Werner \& Broersma, 2008).

These ordered investment options were systematically tested by the 91 respondents from a random survey sent to 573 enterpreneurs who were identified as 'active in tourism in the Wadden area.' The 573 were chosen on the basis of their Chamber of Commerce categorization of activities and their location in one of the 18 Wadden municipalities. ${ }^{8}$ Every entrepreneur was asked to state his or her most preferred scenario A, B,C, or D, and also asked to select 3-5 preferred policy/investment options. Policy options could be chosen from any of the scenarios; in this way, the questions have two levels, one based on the broad direction and the other on concrete actions and detailed policies. All entrepreneurs answered these questions for all three Wadden sub-regions separately, not just for the regions in which they were located or active.

\section{Results}

\subsection{Tourism in Three Sub-areas}

The Wadden area is a very popular tourism area; tourists spend an estimated six million nights in the region each year. ${ }^{9}$ Three areas within the Wadden can be identified: the Wadden islands, the Wadden sea, and the mainland coast.

\subsubsection{Wadden Islands}

The Dutch Wadden islands (also known as the West Frisian islands) have evolved into very popular holiday destinations. The number of nights spent on the islands by Dutch tourists

\footnotetext{
${ }^{8}$ We sent 269, 163 and 141, respectively, to coast, islands and sea entrepreneurs who were considered to be active as tourism entrepreneurs. On the basis of personal communications received from non-respondents, the assumption that they are touristic Wadden entrepreneurs did not always prove correct, especially along the coast some activities were not touristic and some entrepreneurs did not consider themselves residents of the Wadden area. The actual number of 'real' Wadden tourism entrepreneurs amongst the total to whom a survey was sent was estimated at 119,143, and 121. The actual response to these estimates was 21,37 and $33(18 \%, 26 \%$ and $27 \%)$, respectively.

${ }^{9}$ Data on tourism nights at the Wadden islands is readily available, as they comprise one of the tourist regions of Statistics Netherlands; however, they only survey large enterprises. To collect data on tourism to the mainland coast is not so straightforward. 2006 data of Toerdata Noord was used (only available for the 14 municipalities in the provinces of Groningen and Fryslân) to estimate the total. Six million is an estimate of five million tourist nights to the islands in 2008 and 2009 , to which we added $21 \%$ for mainland nights - see below.
} 
during the period 1998-2009 was around four million each year, fluctuating between 3,7 million and 4,2 million. ${ }^{10}$ More than half of all Dutch people have visited at least one of the islands, mostly on family holidays. All tourists generally have longer holidays, although the average length is tending to decrease. Repeat visits are however quite high. Foreign tourists are mainly German (around 90\%), but the number of nights spent by German visitors has decreased strongly, however, whereas around 1,7 million nights was recorded in 1998/1999, the number fell to 1,0 million in 2009. The development of tourism in the competing coastal area of former East Germany is apparently related to decreased visits to the Dutch Wadden islands. ${ }^{11}$ The decline has resulted in the percentage of foreign tourists falling from $30 \%$ to $22 \%$.

Although the Wadden islands are often regarded as a group, there are also marked differences among them. For instance, in the ferry distance and price, Texel, the most western and most popular island, is very near to the mainland and so the price for crossing is low and takes about 10 minutes. Vlieland and Terschelling are the most remote; crossing takes over 90 minutes with the most popular ferries and the cost of crossing is far more expensive. Ameland and Schiermonnikoog, the most eastern islands, are in between.

\subsubsection{Wadden Sea}

The number of recreational sailing movements at the Waddensea has doubled in the last 25 years. Data from Waterrecreatieadvies show that some 350,000 nights are spent on boats in harbors around the Waddensea. The large majority takes place at the Wadden islands (87\%) and the rest at the mainland coast in the harbours of Harlingen, Delfzijl, and Den Helder.

Different categories can be distinguished in tourism activity at sea. First, much of the recreational sailing takes place on sailing ships; there is a trend taking place towards more luxurious, larger boats, that mainly navigate through the large fairways in the western Waddensea. A second category consists of shallower boats that sail the ecologically more vulnerable east-west route; they may anchor and 'fall dry' with low tide. A third category includes almost 400 ships of the charter fleet ('brown fleet'), which carry recreational and tourist groups.

A modest but stable form of recreation, namely mudflat walking, is mainly undertaken in the eastern Wadden area.

\subsubsection{Mainland Wadden Coast}

The mainland coastal area is part of the economic periphery in the Netherlands. The nights

\footnotetext{
${ }^{10}$ Statistics Netherlands, online database Statline concerning 'Gasten in alle logiesaccommodaties; naar herkomst en toeristengebied'. Accessed April 2011.

11 Data from the GENISIS database of the Federal statistical office in Germany (Übernachtungen in Beherbergungsbetrieben: Bundeslanänder, Monate, Wohnsitz der Gäste, accessed on 10 April 2011) show that inland German tourism nights in Mecklenburg-Vorpommern have increased strongly in the last two decades (fueled by the fall of the Iron Curtain). Inland tourism nights have tripled over nearly two decades, from 9 million in 1992, to 18,5 million in 1999 , and a whopping 26,5 million in 2010 . The share of foreign tourism in Mecklenburg-Vorpommern has remained very modest, around 2-3\%.
} 


\section{Mll Macrothink}

spent by tourists in the area was estimated at around 21\%: one million each year (Sijtsma, Werner \& Broersma, 2008). ${ }^{12}$ The area is mostly rural, but there are some smaller size cities. The industrial harbor cities include Den Helder, Harlingen and Delfzijl; they are at present concentrating on their development, which includes, but is definitely not limited to touristic and recreational activities. Large events serve as a strong crowd-pullers in the touristic category. In 2008 more than 600,000 visitors flocked to see Delfsail in Delfzijl, and the Tall Ships Race in Den Helder attracted around 350,000 visitors. The rest of this peripheral area is a haven of peace and quiet, especially compared to the high density hubbub of the Randstad. Tourism in rural areas is mainly concentrated in municipalities Wûnseradiel (the IJsselmeer) and the Marne (the Lauwerslake area). Furthermore, outside the cities two day-attractions are very popular: the seal sanctuary in Pieterburen (De Marne) and Fontana Spa Nieuweschans (Reiderland).

\subsection{Historical Development at the Islands}

Figure 1 on the left axis shows the number of passengers to and from Terschelling during the period 1900-2005, and allows for a more precise designation of tourism development stages. The figure is based on yearly data of ferry crossings between Harlingen and Terschelling while our interpretation is based on an analysis of newspaper articles on Terschelling from its reputable regional paper. On the right side axis of Figure 1, number of nights spent at the island are shown. This graph is used to classify the development of tourism using the TALC.

\footnotetext{
12 Toerdata Noord data for 2006 show a total of 8,7 million nights at the Wadden islands, and 1,7 million in the Frisian and Groninger Waddencoast municipalities (Sijtsma, Werner \& Broersma, 2008). Toerdata Noord includes many smaller enterprises in its survey which Statistics Netherlands leaves out. The size of the 3 North-Holland coastal municipalities was estimated by using the employment in the hotel and catering industry and multiplying it by the ratio of nights per employment in the hotel and catering industry (3202 nights per employed person) of the Frisian/Groningen mainland coast municipalities. Leading to a total of 2,3 million nights for the mainland coast: $21 \%$. This ratio has been applied to the total of Statistics Netherlands for the islands.
} 


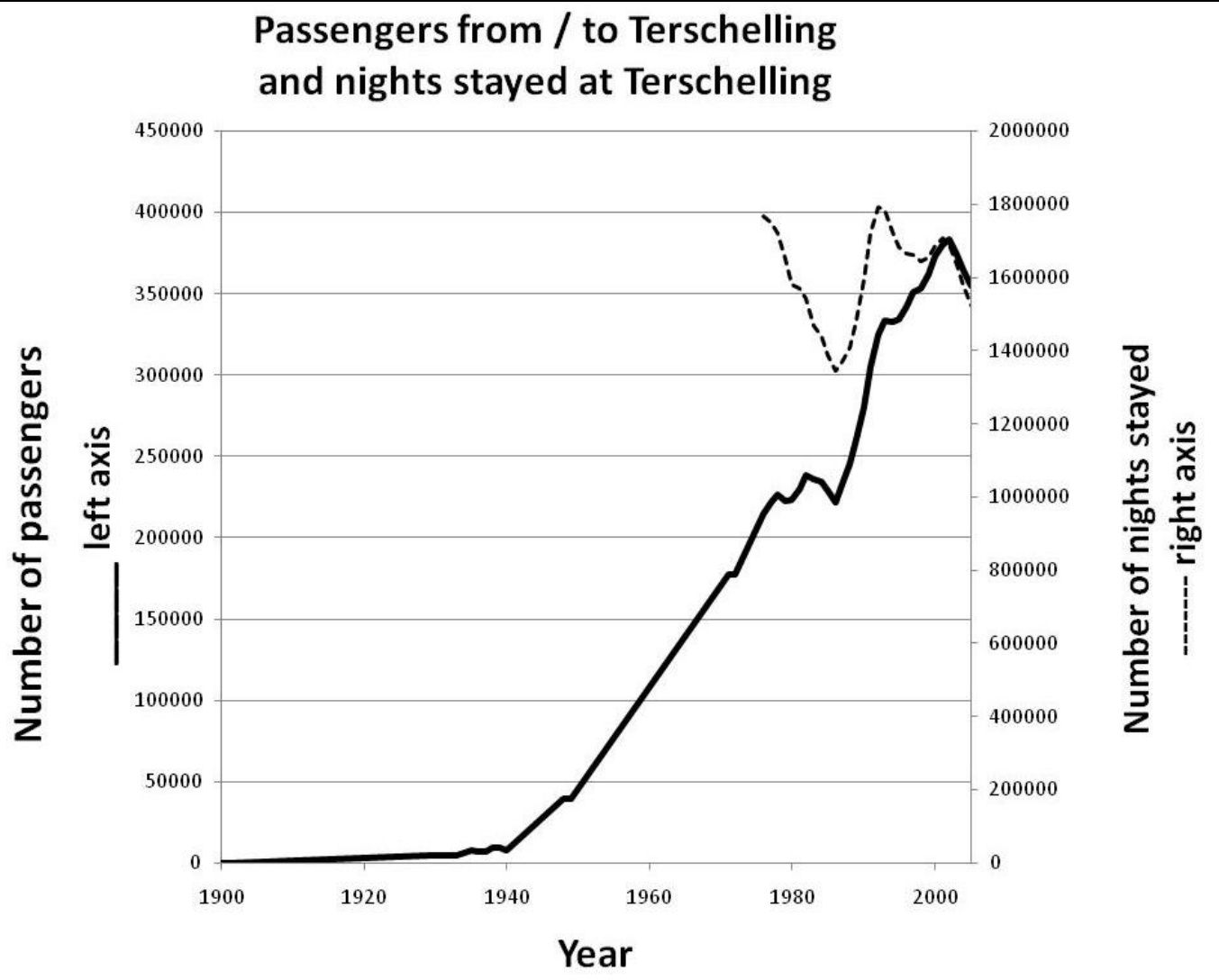

Figure 1. Passengers to and from Terschelling during the period 1900-2005; nights at Terschelling 1976-2005

Using figure 1 and the articles in the regional newspaper, it is possible to define the stage of exploration in the period prior to 1910 , where there is mention of occasional visits, but those who have taken the journey were clearly explorers. The involvement stage is determined to be from 1910-1920. By this time, a tourist information organization has been set up; there is some activity in improving accessibility of the ferry - which had been used for mail delivery and local people transport until then. The development stage is the longest, from 1920 until 1980. In the early 1920s, paved roads were starting to be built leading to the bathing areas on the island. Advertising began and personnel were employed to serve tourists (in bakeries, for instance) from newspaper advertisements; also from 1930 passenger boats rather then mail delivery boats were used. In 1948 some 50,000 vacationers visited Terschelling during the high season. From 1970 problems arose concerning car mobility and this issue remains a major policy issue today, but at the time some form of social-environmental limitation was under discussion. From 1980-2000 onwards, a period of consolidation took place. In high season the island tourism capacity was used fully and a deliberate policy of no further overall capacity growth was enforced. Growth was occurring out of the touristic season. In the present period, passenger growth is still witnessed, but nights spent at the island do not increase accordingly due to (relative) shorter stays. It is mainly quality investment that is being made, rather than the idea of quantity of investments. Starting in 2000, a definite phase of stagnation begsn, but it is necessary to verify this trend; to refine our understanding of the phases of development employment figures are examined. 


\section{Ml Macrothink}

Figure 2 places tourism development in a perspective of regional economic development. The figure shows employment in the main sectors of the Terschellinger economy over a 100-year period, and although employment largely follows the growth in passengers shown above, the overall effect of figure 2 is rather more subtle. At the beginning of this period, the island was occupied mainly by agricultural and fisheries and/or maritime activities - this was the time when tourists explored the island.

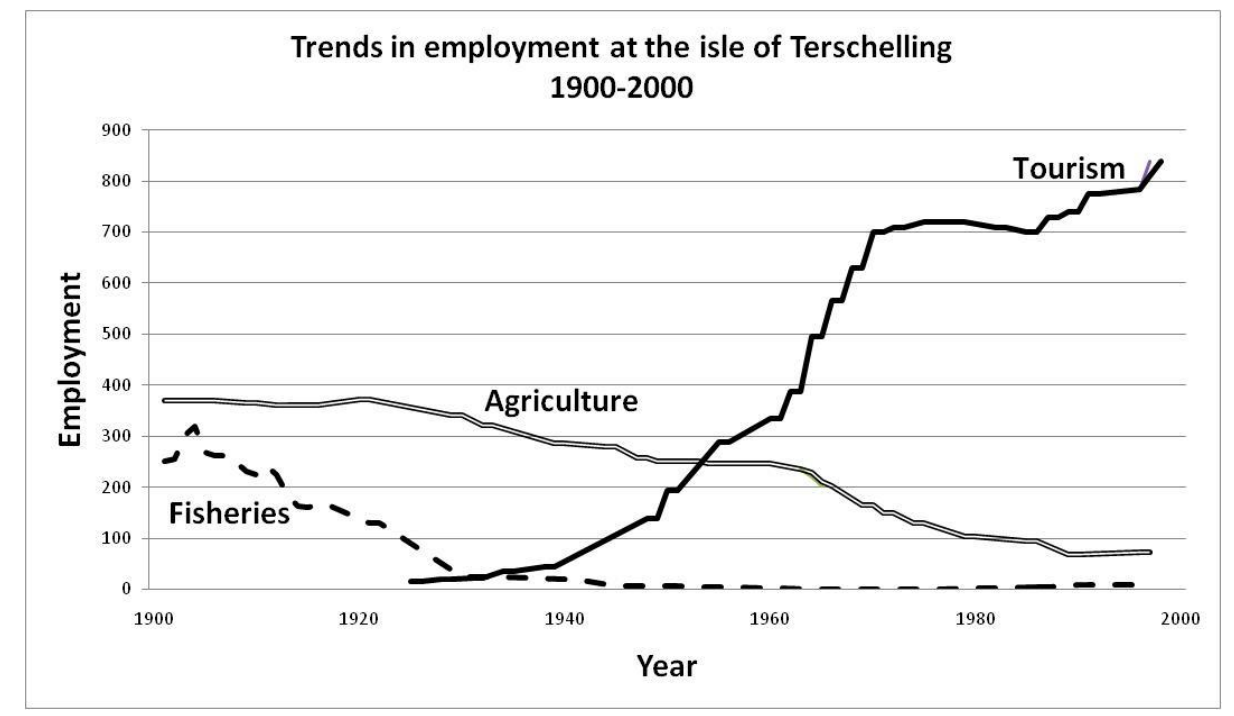

Figure 2. Employment at Terschelling in the three main sectors of the economy (1900-2000).

Source: Ferry and municipality administrations

The period from 1900 to 1945 in figure 2 shows the complete disappearance of fisheries and maritime employment. As the decline intensifies, it is possible to observe the start of the involvement phase; once the sector has virtually disappeared, the development phase then sets in. The time period 1945-1970 represents a cross-roads period in which agriculture is still important, but tourism is gradually and steadily also becoming a substantial activity for the island economy. In hindsight, it appears clear that tourism was 'taking off'. From our analysis of newpaper articles, however, during this time period - and for many years - it was not clear whether tourism would continue to flourish or if agriculture would emerge as the preferred economic activity on which to build the local economy. After 1970, agricultural employment reduced to a very modest amount. Not only has tourism grown to a consolidated phase, the island economy is in the present day entirely dominated by tourism.

\subsection{Current Tourism Employment}

For a thorough understanding of tourism in the regional economy employment data is of critical importance. During the rise in the Dutch economy over the period 1996-2007, the Wadden area as a whole lagged in terms of employment growth (Sijtsma, Werner \& Broersma, 2008, p.10-12). If one distinguishes between the islands and the mainland coast, the Wadden islands clearly performed the best during this period; only in later years did they lag somewhat behind the national growth rate. However, it is the mainland coast that clearly dominates the whole region and is also responsible for the poor performance compared to the 


\section{Mll Macrothink}

Dutch average.

Although total employment growth could not keep pace with the national trend, tourism proved to be a relatively strong sector in the Wadden area. Interestingly for tourism, there was only a modest difference between the growth rate of tourism at the Wadden islands $(19,8 \%)$ and that of the mainland coast $(17,6 \%)$ during this time period. For the weakly performing coastal area, this was a growth rate four times the average in its overall economy. Due to this relatively strong growth, tourism gained importance in the total economy, as figure 3 shows. The share of tourism in total employment has grown to nearly $40 \%$ at the Wadden islands, revealing a very high degree of specialization. The share of tourism at the mainland coast was below the national average of $8,5 \%$, but in this period caught up substantially, and began moving closer to the national average.

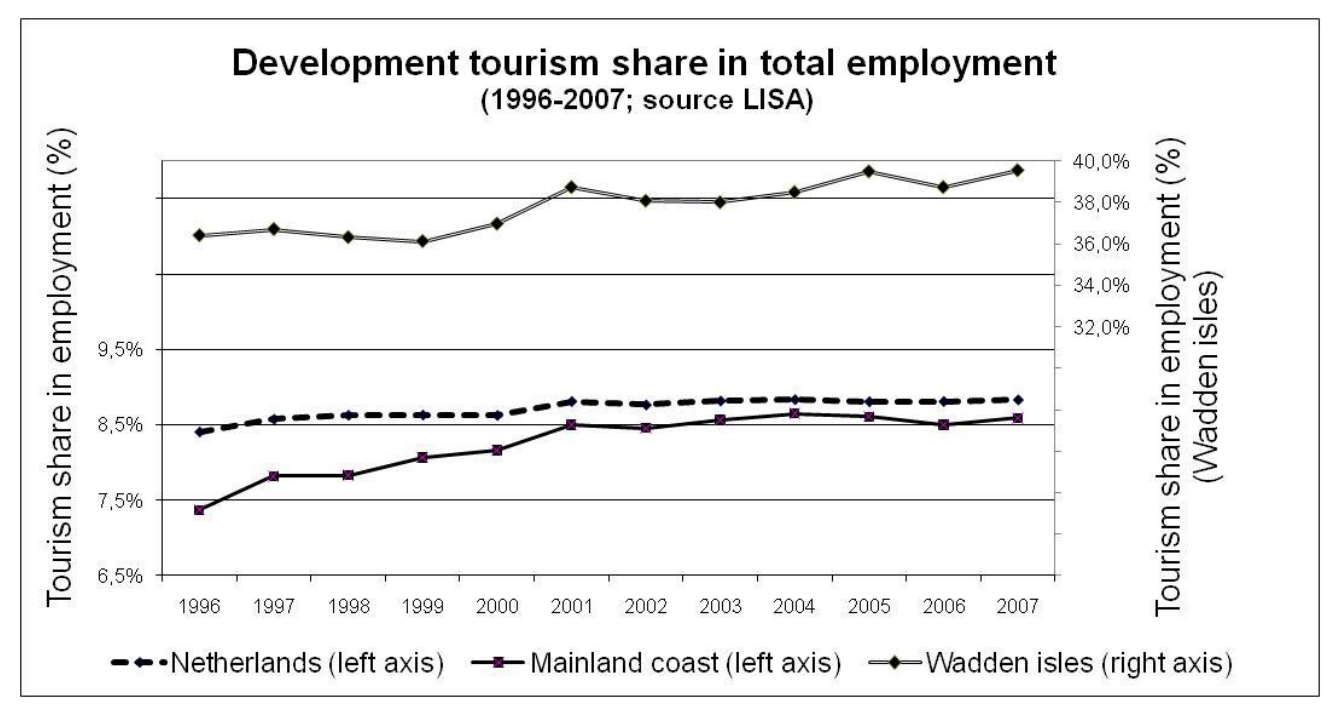

Figure 3. Tourism employment in the Netherlands, the Wadden islands and the mainland Wadden coast (1996-2007). Source: LISA.

In figure 4 a more spatially-detailed view of the tourism economy in the Wadden area is presented. Figure 4 shows the tourism industry as part of the Wadden economy and is based on employment data from the LISA database for year 2007 (Sijtsma, Werner \& Broersma, 2008).13 Employment is measured here as the total number of all jobs, including small ones from 1 hour (+) per week. Figure 4 shows the 18 Wadden municipalities in two groups. On the left, the five Wadden island municipalities are shown, on the right, the municipalities on the mainland coast are depicted. Both groups are shown from west to east.

${ }^{13}$ Permission for data use was given on behalf of the Raad voor de Wadden (Sijtsma, Werner \& Broersma, 2008). 


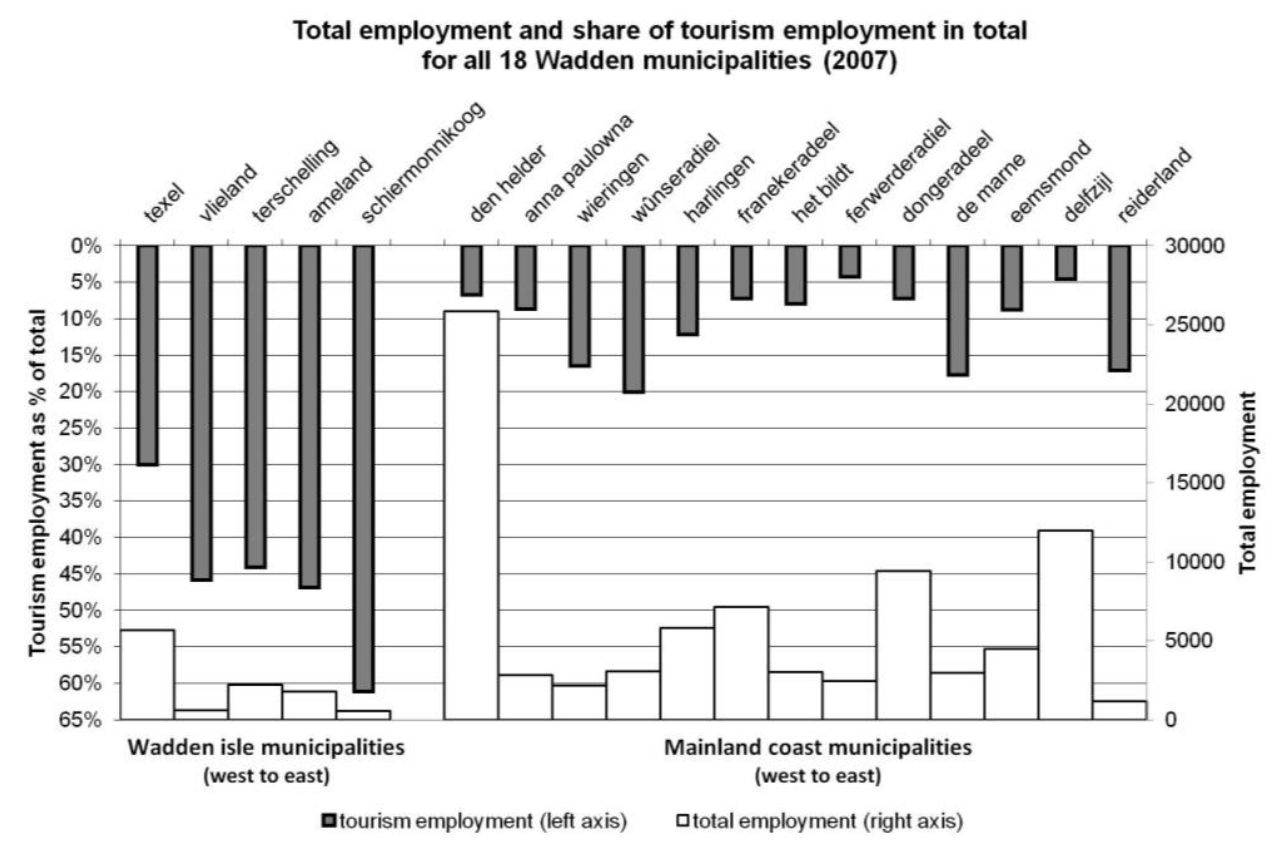

Figure 4. Employment and tourism employment in the different municipalities of the Wadden area (2007). Source: LISA.

The overall economic structure of the Wadden area is clearly shown. The Wadden islands are indeed small 'island economies'. Texel is by far the biggest island but still has only around 5000 jobs, Terschelling and Ameland have around 2500 jobs, while Vlieland and Schiermonnikoog have around 500 jobs. The Wadden islands have huge shares of tourism employment, ranging from $30 \%$ for Texel to over $60 \%$ for Schiermonnikoog.

At the mainland coast, Den Helder is the largest municipality in total employment, with over 25,000 jobs in 2007. Employment here is dominated by the Royal Dutch Navy in Den Helder and by employment connected to the oil and gas activities in the North Sea. After Den Helder, Delfzijl and the municipality of Dongeradeel have the most jobs (especially in Dongeradeel the city of Dokkum, which is not directly located at the Wadden Sea). Reiderland and Wieringen have relatively few jobs.

Tourism is much more limited at the mainland coast; it ranges up to $20 \%$ in Wûnseradiel (mainly located at the IJsselmeer) and De Marne (Lauwersmeer). Tourism employment is around $7 \%$ of the total employment in Den Helder.

From this analysis of employment one can observe that, at the islands, tourism is not in a stage of stagnation. This completely specialized economy shows continuous growth potential. At the mainland coast tourism has performed quite satisfactorily in recent years, but remains rather unimportant in the economy as a whole.

\subsection{Future Developments}

\subsubsection{Entrepreneurial Views on the Broad Directions of Tourism}

Development and evolution of tourism areas are not 'a given', but rather are also determined by 


\section{Macrothink}

policy, entrepreneurs, and the consensus among them. To assess the possible future development let us now turn to the consensus in the industry (Hovinen, 2002). ${ }^{14}$

In the survey, tourism entrepreneurs from the three Wadden areas: islands, Waddensea and mainland coast, were asked which of the policy and investment scenarios A,B,C, or D they preferred. Unexpectedly, there are only minor differences between entrepreneurs from the three sub-areas of the Wadden as to the broad direction of all sub-regions; the results for all sub-regions together are shown in figure 5. Eighty-three valid replies were received on this question for the islands, 85 for the sea, and 88 for the mainland coast ( 85 on average). A large majority of votes went to the right side of figure 5; most entrepreneurs support a future scenario with investment options that preserve the Wadden identity as it is in the present day. Concerning the focus on number of visitors, the votes are divided nearly equally between the upper and lower part, with a slight tendency towards more vistors. Nevertheless, both scenarios serving the 'happy (wealthy) few' as well as those serving large numbers of visitors, receive considerable support from entrepreneurs.

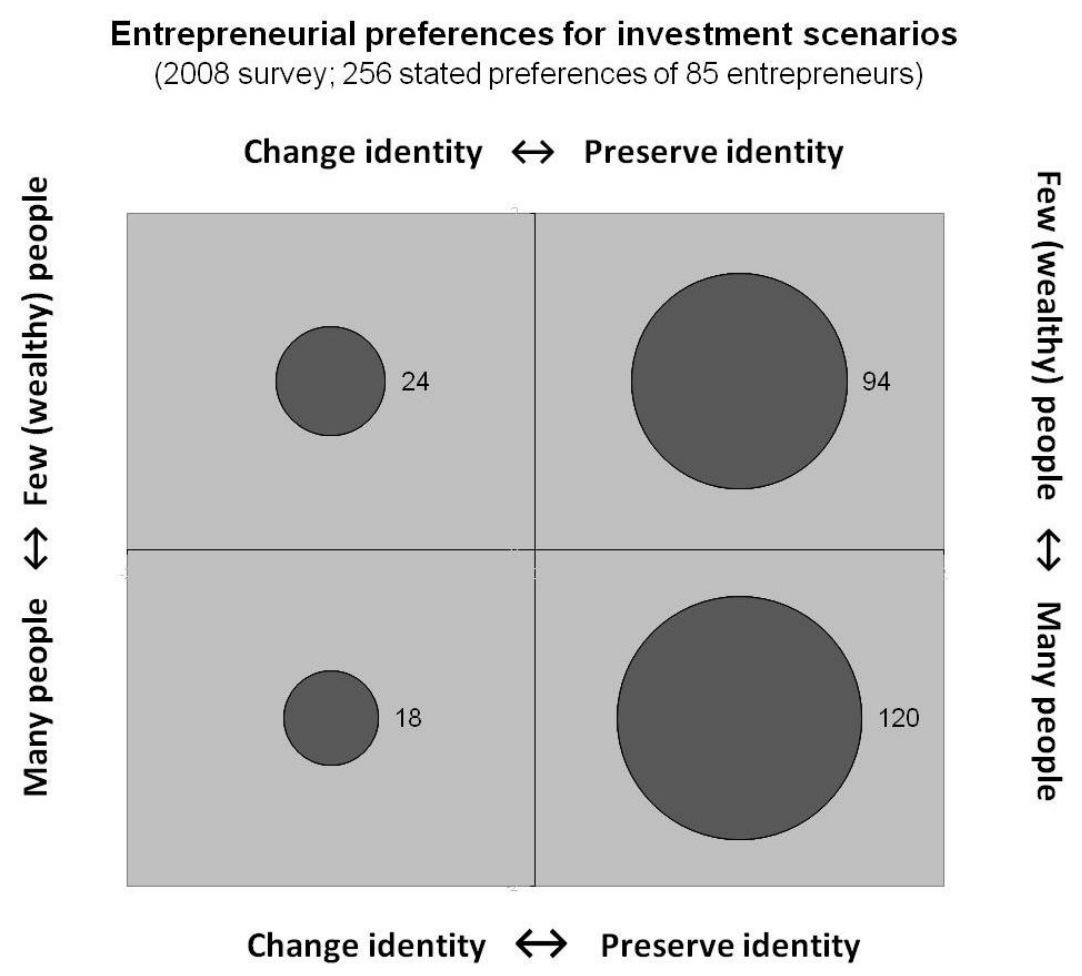

Figure 5. Entrepreneurial scenario preferences

\subsubsection{Entrepreneurial Views on Concrete Future Investments and Policies}

The scenario preference was the first question, but entrepreneurs were also asked to state their preference for more specific and/or concrete policy/investment options. Table 1 shows

\footnotetext{
${ }^{14}$ Compare Hovinen, 2002, (p. 220): 'This is one of a number of signs of a lack of consensus in the industry, which might make any future effort at strategic planning more difficult to accomplish.'
} 


\section{Macrothink Institute ${ }^{T M}$}

the four most preferred options; the options with the biggest consensus; grouped for the islands, the sea and the mainland coast separately.

Table 1. Percentage of entrepreneurs favoring different investment options (showing 12 out of 81 options with more than $35 \%$ of the entrepreneurs favoring the options)

\begin{tabular}{|c|c|c|c|}
\hline $\begin{array}{l}\text { Option } \quad \text { from } \\
\text { sce-nario: }\end{array}$ & $\begin{array}{l}\text { For } \\
\text { sub-area: }\end{array}$ & Investments in: & Percentage: \\
\hline $\mathrm{D}$ & Islands & Playful education about (awareness of) the Wadden & $42,2 \%$ \\
\hline $\mathrm{D}$ & Islands & Free foraging nature areas & $39,8 \%$ \\
\hline B & Islands & Experiencing sustainable holiday tourism & $36,1 \%$ \\
\hline B & Islands & $\begin{array}{l}\text { Ecological products from the Wadden area as part of tourism } \\
\text { stay }\end{array}$ & $36,1 \%$ \\
\hline B & Coast & Purity, clean environment & $53,4 \%$ \\
\hline B & Coast & $\begin{array}{l}\text { Perception of peace and quiet as opposed to the hectic urban } \\
\text { core }\end{array}$ & $48,9 \%$ \\
\hline $\mathrm{D}$ & Coast & More bicycle facilities & $40,9 \%$ \\
\hline B & Coast & Maintaining the open landscape & $36,4 \%$ \\
\hline B & Sea & $\begin{array}{l}\text { Organized Wadden arrangements (fishing, eating, } \\
\text { story-telling, etc.) }\end{array}$ & $44,7 \%$ \\
\hline B & Sea & $\begin{array}{l}\text { Protecting the Waddensea horizon (beautiful views of } \\
\text { boats/coast) }\end{array}$ & $43,5 \%$ \\
\hline $\mathrm{D}$ & Sea & Protecting silence and darkness & $38,8 \%$ \\
\hline $\mathrm{D}$ & Sea & Educational Wadden excursions & $35,3 \%$ \\
\hline
\end{tabular}

For all sub-areas the current ecological and landscape qualities are seen as an important base for the future. At this concrete level, scenarios B and D still dominate. But the table also shows the 'close call' between the dominance of either scenario B or D. D appears to be dominant at the general level (Figure 5), but at this concrete level, the investment options for $\mathrm{B}$ are the most preferred for the sea and the coast, while those for D are the most preferred 
only at the islands.

Table 2 shows the most and least preferred option of scenarios $\mathrm{A}$ and $\mathrm{C}$ for every sub-region. This table serves to show, on the one hand, the consensus on what not to invest in. It is clear that there is little interest in amusement parks, either at the islands or linked to the sea. For the coastal area, and remarkably, there is little interest in developments such as the recently established and commercially successful large scale holiday park at the Lauwersmeer area ('Esonstad').

The table also shows the investments with the highest support in scenarios A and C; this may serve to identify a potential 'lack of consensus' by a substantial minority which does not support the overall consensus for B or D. At the islands a resolute minority among the entrepreneurs opts for paved paths on the dunes, thus making these dunes far less natural, but giving improved access. Furthermore, support is found for more festivals and events like the successful open-air-across-the-island theater festival 'Oerol' at Terschelling. At the sea, there is plenty of support for more dredging of ports and expansion of marinas; this issue is always heavily debated due to possible direct (dredging) or indirect (more boats) impacts on the heavily protected sea. The mainland coast opts for more beaches; entrepreneurs probably consider the success of beaches at the islands (although these are ecologically difficult to realize compared to the islands as the mainland coastal area is muddier than it is sandy). The mainland coast also has some support for ready-made travel packages.

Table 2. Percentage of entrepreneurs favoring less preferred and non-consensus investment options (showing 12 out of 81 options in scenarios A and C, which are the most and least popular with the entrepreneurs)

\begin{tabular}{|l|l|l|r|}
\hline Option from sce-nario: & For & Investments in: & Percentage: \\
\hline \multicolumn{2}{|l|}{ The two least preferred options of A and C } & $2,4 \%$ \\
\hline C & Islands & Amusement parks & $1,2 \%$ \\
\hline A & Islands & Sauna units at the beach & $2,3 \%$ \\
\hline C & Coast & More holiday parks such as 'Esonstad' & $1,1 \%$ \\
\hline A & Coast & Five star hotels & $7,1 \%$ \\
\hline A & Sea & More space for motor yachts & $5,9 \%$ \\
\hline C & Sea & Large-scale water amusement park & $16,9 \%$ \\
\hline The two most preferred options of A and C & \multicolumn{2}{l|}{ Paved path on the dunes, wooden ramps to the beach } \\
\hline A & Islands &
\end{tabular}




\section{Macrothink}

\begin{tabular}{|l|l|l|r|}
\hline C & Islands & Large-scale expansion of events (such as 'Oerol') & $14,5 \%$ \\
\hline C & Coast & More beaches + facilities & $21,6 \%$ \\
\hline A & Coast & Ready-made travel packages & $15,9 \%$ \\
\hline A & Sea & Dredging ports & $24,7 \%$ \\
\hline C & Sea & Expansion of marinas / moorings & $18,8 \%$ \\
\hline
\end{tabular}

\section{Discussion}

At the start of the paper it was mentioned that tourism has a special place in the search for sustainable development, since it may combine both the appreciation of the natural qualities of the area (Sijtsma, Daams, Farjon \& Buijs, 2012) as well as provision of income and jobs to the local community. In this search, what do the results found here suggest about the direction of tourism; to which evolutionary stage will tourism turn in the different sub-regions, and what policy dilemmas do they face concerning tourism and sustainable development?

\subsection{Policy Dilemmas}

Already in 1982, Hovinen argued that the magnitude of a potential decline in a tourism area is linked to the diversity of the tourism base and the effectiveness of ameliorative planning (see Getz, 1992, p. 754). Given these elements, which topics for ameliorative planning can we see, or what dilemmas exist for tourism policy for the Wadden area?

At the islands: the happy few versus the masses

An increased focus on the higher segment, with higher prices and fewer but more wealthy visitors, may lead the islands to stronger exclusivity and sustained competitiveness of the tourism industry. Such a development would, however, not correspond with a Wadden experience for everyone (Khan, 1997; Van der Aa, Grootte \& Huigen, 2004). ${ }^{15}$ The responses to the survey clearly highlight this dilemma: there is considerable support for development for the happy few and also for the majority of the so-called masses.

The elite versus masses dilemma facing the industry at the islands raises the question of how to combine development for fewer but wealthier people with the desire for permanent or (even) increasing accessibility for many people, rich and poor. Can more same-day visits be an option for growth within environmental limits-even though the questionnaire indicates little enthusiasm from entrepreneurs for this? Does the minority favoring more events and festivals have a valid point? Can this represent a middle way, meeting a high degree of consensus (see below)?

At the sea: Balancing economy, ecology and safety

Specifically for the sea, the dilemma of marina expansion is a significant problem. Growth in the number and size of ships (the happy few...) leads to heavy and often over-used marina

\footnotetext{
15 And which the World Heritage status seems to strengthen. Compare [28] on the divide between mass tourism and eco-toursim and [29] on the tensions surrounding World Heritiage status.
} 
capacity during the 6-8 weeks of the high season. Larger marinas are often seen to negatively affect ecological values. With overcrowded marinas boats often anchor outside the harbor, thereby posing safety risks for the tourist crew. How can a clear balance be found? Do larger marinas, as well as the monitoring of non-disturbing behavior of yachts, provide enough ecological quality (see below)?

For the ecologically-vulnerable eastern part of the Dutch Waddensea the persistent policy dilemma is how to arrange for ecologically-safe sailing activities without limiting access. Charter boats may prove to be the champion vehicle solution to this dilemma, since many people from all walks of life can travel using this mode, while at the same time it may be relatively easy to monitor the limited number of professional captains with regard to their ecologically behavior.

\section{At the mainland coast: just space or tourism space?}

As outlined above, although tourism is growing in the mainland coast area, further development in the whole area seems to entail a greater absolute importance to the regional economy in order to prevent tourism attractiveness from being impacted by industrial and other economic developments that would share the same space.

Table 1 shows a distinct difference in the life cycle of tourism activities, especially if the life cycle is considered in conjunction with the degree of specialization of the local economy on tourism (see below). At the islands and for the sea, the investment options are typical for a mature, well-developed tourism sector in a specialized economy. Playful education, combining ecological products, organized Wadden arrangements, and educational excursions: these are concrete and strengthening options. But we do not envision this for the coastal areas. Table 1 indicates that preserving the current identity is highlighted here as well. But what type of strategy is this when, at a more concrete level, the most preferred option with the largest consensus, is more bicycle facilities? Two aspects suggest that these are not signs of a developing tourism sector; firstly, biking is an extremely modest activity at the coast compared to many other Dutch regions, including the Wadden islands. Relatively strong winds, long routes and sparse numbers of trees hinder biking activity and it is expected that this will be the case in the forseeable future. In contrast, there is no support for large-scale holiday parks although space is not an issue, and the recent initiative (Esonstad) shows clear potential. And secondly, that the coastal region is pure and clean may be valid from a tourism perspective but recent years indicate that environmentally-speaking, highly unclean industrial development takes precedence over tourism. The city of Harlingen has approved a large waste burning plant. At Eemsmond, a series of enormous new power plants will be built, one of which is coal-fueled. These developments do not ostensibly fit into the investment strategy of a pure and clean environment.

A major policy dilemma may be that enduring growth can hardly be realized without a strong regional economy. Otherwise, the 'mere space' attractivity of the region will dominate the 'tourism space'. Stronger growth would require a quantitative ambition supported by creative branding. Obviously, a strong brand may indeed be the rest of Wadden area, the islands and 
the Waddensea, with its World Heritage status. But how might the mainland coast profit from this brand in a quantitative way (attracting a greater number of visitors) when, at the present time, the attractiveness of the area is limited? And when there is little consensus on the option of substantial quantitive expansion of tourism? A final question remains: how may the area address other environmentally-detrimental developments within the regional economy which also appreciate available space for industrial purposes, and which appear to have greater political and economic bargaining power due to being a more substantial part of the regional economy? A challenging dilemma indeed.

Policy and entrepreneurial efforts effectiveness seems to depend on both knowledge of spatio-temporal variation in past developments and consensus regarding directions in the future development of the tourism sector (compare Dodds \& Ko, 2012). Knowledge of past developments can be derived from the analysis of tourism-indicators including visitor nights, ecological quality, employment and employment-based location quotients. However, our analysis emphasizes that the viability of different future directions is difficult to derive from these conventional indicators. Surveying entrepreneurs shows to be a useful means to improve the understanding of possible futures of the Wadden area's tourism sector. Its potential to both reveal the degree of consensus among entrepreneurs for alternative development options and to uncover policy-relevant information not included by regional economic statistics make surveys a valuable monitoring instrument (Daams \& Sijtsma, 2013). ${ }^{16}$

\subsection{Monitoring Sustainability: TALC-4q}

How might the development of the Wadden area be assessed in terms of the life cycle of tourism areas (TALC)? The analysis above has addressed the number of visitors: the key variable in the TALC. At both the islands and the sea, tourism seems to be 'mature' (Hovinen, 2002). Following Getz and Hovinen, mature may be the better term, since 'elements of consolidation, stagnation, decline, and rejuvenation co-exist' (Getz, 1992, p. 762). Tourism at the mainland coast is at best in a development stage.

However, the analysis and discussion above have demonstrated that in order to understand, monitor and manage the Wadden area more perspectives are needed than merely the one offered by TALC. Although the TALC addresses the issue of different future routes after the stagnation/maturation phase, the framework itself provides few clues about the causes for one development or another in terms of measurement and monitoring. In summarizing the discussion above, and in line with the literature aiming at more context and adaptivity in tourism concepts (Farrell \& Twining-Ward, 2004)) it would seem that a broader analytical framework is needed. Therefore, a TALC framework with four quadrants is proposed here: TALC-4q (see figure 6). It is a framework with a measurement and monitoring focus (Butler, 1999). The four 'quadrants' share a common time x-axis, but have different $y$-axes. The first

\footnotetext{
${ }^{16}$ The use of survey-panels of entrepreneurs and other innovative techniques that may fill in gaps in existing monitoring practices will be reviewed by the Wadden Sea Long-Term Ecosystem Research (WaLTER) project (www.walterwaddenmonitor.org).
} 


\section{Macrothink}

quadrant, the core of the TALC, is the market perspective and the starting point of this framework. The other three quadrants are counterclockwise, the ecological/natural, the rural labor market, and the policy perspective. Within every perspective one or two key performance indicators are shown along with their possible movement over time. If there are two indicators, the second one is shown on a secondary y-axis. The curves drawn in the different quadrants differ in how thick they are drawn to indicate relative importance over time: the thicker the more important the indicator is (at that moment in time).

The first quadrant shows the well-known TALC curve. In the earlier stages (and say at t0) the growth of the absolute number of visitors is important. When the stagnation or mature stage is reached (around t1), the absolute number may not be critical from a market perspective. Keeping in mind the decreasing number of German tourists who visit the Wadden area because they have found a competing coastal area in eastern Germany, this indicates that market share really is the key performance indicator relevant at this stage. Absolute numbers may increase or decrease for many reasons, but the monitoring of market share (eventually for different market segments or different types of attractivity (Sijtsma, Daams, Farjon \& Buijs, 2012) is in many industries the key indicator for competitiveness. This is why we have thickened the market share curves.
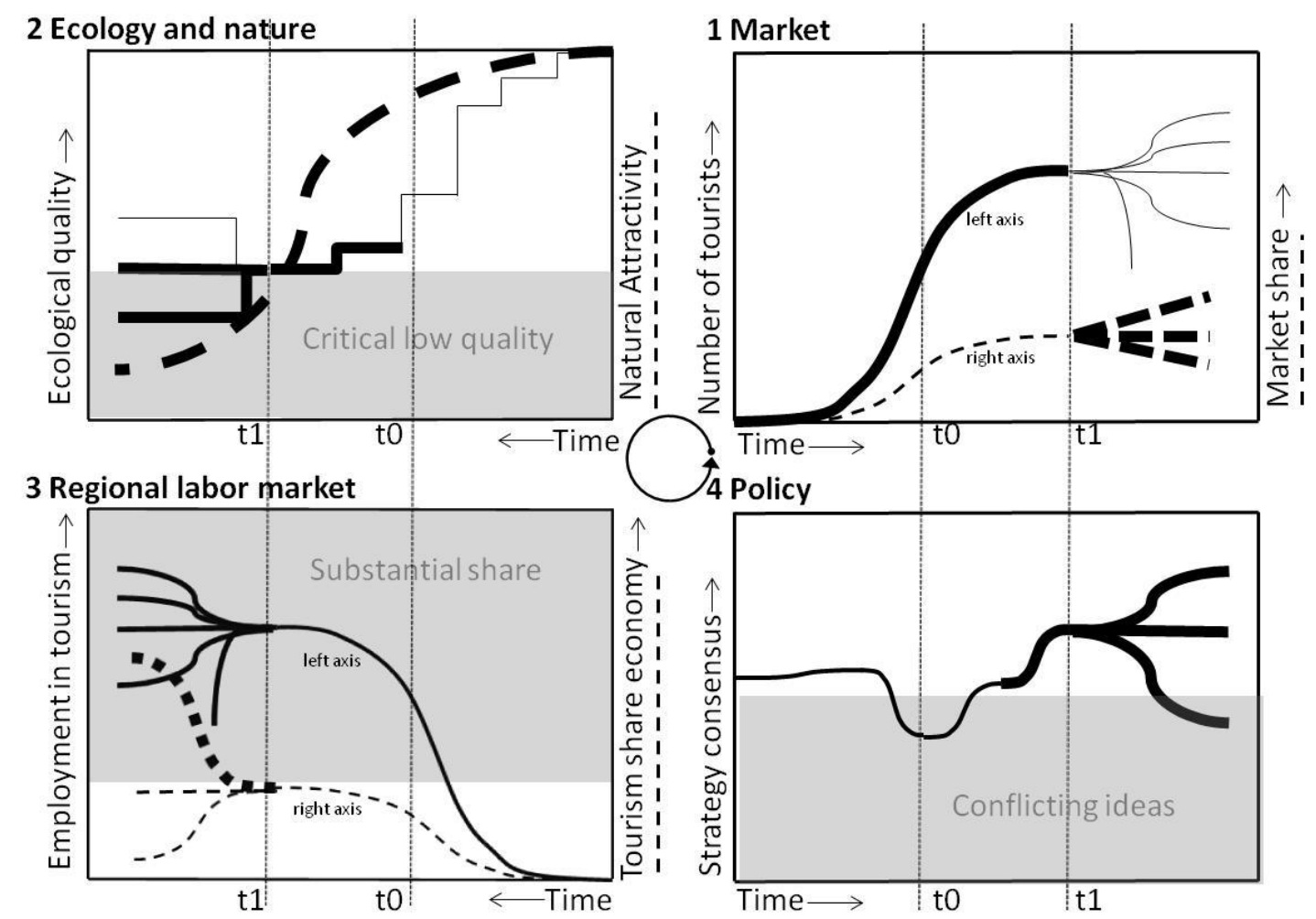

Figure 6. TALC-4q - the Tourism Area Life Cycle in 4 quadrants and perspectives: Market, Ecology and nature, Regional Labor Market and Policy

To understand, monitor and manage future developments of the tourism area, additional perspectives are nonetheless needed. The second quadrant show the ecology and nature perspective. Clearly this is relavant to areas, like the Wadden area, which attract visitors 
because of their natural capital. The quadrant measures the ecological quality of the area on the left hand y-axis. As shown above in the Wadden area several nature protection schemes are in place and already for a long time. Several monitoring variables may serve here, and these may be aggregated to a single variable too (e.g. Sijtsma, Van der Heide and Van Hinsberg, 2013). Regardless of the particular indicator that is chosen, clearly for a nature-based tourism area it is essential to safeguard its ecological capital (Hernández \& León, 2007); while it is also clear that the development over time need not follow the shape of the TALC curve. The ecological perspective has a secondary y-axis, showing the natural attractivity of the area to visitors. Different units of measurement may be applied here, for instance the hotspotindex (Sijtsma, Farjon, Van Tol, Van Hinsberg, Van Kampen, \& Buijs, 2013; De Vries, Buijs, Langers, Farjon, Van Hinsberg, Sijtsma, 2013). In some respects this is obviously related to the ecological quality as such, but in other respects this may be unconnected since for instance the view on the horizon or the sound of the waves on the beach may be an important part of the visitor attractivity but may hardly matter to the ecological quality. Obviously, in the early stages of tourism the impact of tourism may be small (and monitoring may be less important perhaps even up to t0) but once serious ecological damage has occurred and especially if critically low quality is approached or even reached the importance of monitoring key ecological indicator(s) becomes more important (at around t1). If critical levels are reached, the natural attractivity to visitors is likely to suffer too. Interestingly, if environmental limits are safeguarded, as in large parts of the Wadden area, then the mature stage may be long. Already in his original life cycle paper, Butler (1980; $2006 \mathrm{a} / \mathrm{b}$ ) asserted that some areas may escape periods of decline or the need for rejuvenation to prevent decline. Butler mentions those areas 'in which the development is kept within predetermined capacity limits' (1980,p.11; 2006a/b), may experience very long periods of continued attractiveness. Furthermore, 'in the case of the truly unique area, could one anticipate an almost timeless attractiveness', and 'many established tourist areas [...] attract visitors who have spent their vacations in these areas for several decades and the preferences of these repeat visitors show little sign of changing' (1980; p.8).

The third quadrant, the regional labor market perspective, shows the development of tourism employment. The curve here largely resembles the TALC curve shape of the first quadrant, as it was witnessed above for Terschelling (in figure 1). Employment, its development, and size are key variables from a regional labor market perspective. However, this third quadrant also highlights the tourism share in the regional economy as a key variable. In the analysis conducted here. the relevance of this indicator was emphasized, particularly the relevance of having or achieving a substantial share in the regional economy. Tourism development cannot be taken for granted over time (the main point of the original TALC framework!), and continuous policy support of some sort is recommended as beneficial (Hovinen, 2002). Having a substantial share in the economy seems to be a prerequisite for effective policy making, and is often necessary for acquiring sufficient (public) investment. Fairly robust employment growth has been found at the Wadden Islands. The islands have a completely specialized local economy which, for its own sake, is continuously monitoring the environmental limits of tourism activity, but by also being backed by its substantial share of 
the economy, is also investing in new opportunities and greater quality in order to remain competitive (Agarwal, 1997; Sijtsma, Werner \& Broersma, 2008; Getz, 1992; Hoekstra, 2009). The steady and strong employment performance, despite a decline in the important German market segment, is typical of a highly specialized mature tourism economy, as one which may not be automatically stable or non-declining, but which is nonetheless vital and innovative in a competitive environment. Data for other coastal areas, e.g. British seaside destinations (Agarwal, 1997) ${ }^{17}$ and 'sun-and-sand' Benidorm (Claver-Cortés, Molina-Azorín \& Pereira-Moliner, 2007), show that this is not an uncommon phenomenon for mature locations elsewhere (Vera-Rebollo \& Rodríguez-Sánchez, 2010).

Lastly, the fourth quadrant sets out the policy perspective. The key indicator here is consensus about the direction of development. Without a reasonable (amount of) consensus among stakeholders, i.e. entrepreneurs, public policy makers and NGOs about the direction that tourism development should take, the chances of positive development decrease (Russell \& Faulkner, 2004; Baum, 1998). Even if funds and support are available due to the importance of the regional economy, without a shared focus, investment is not likely to be effective (compare Hovinen (2002) as quoted in footnote 14 above). The above results of the assessment of consensus on policy and tourism directions show that the (net) size of the circles from figure 5 (or the average percentage shares from table 2), can represent a starting point for the measurement of consensus. A strong commitment to the preservation of the ecological and landscape identity of the area has been noted.

In order to highlight the interrelatedness of the four quadrants, the reader is asked to recall the situation and development of the mainland Wadden coast. Along the mainland there is some tourism growth: a modest number of visits (q1) and no serious environmental limits (q2) have yet arisen. However, we would finally like to highlight the difficulty of discussing tourism in the 'mainland coastal area' because it does not appear to be an area of common attractiveness (Sijtsma, Daams, Farjon \& Buijs, 2012). In a way then, tourism in the mainland Wadden coast may be understood as having elements of the involvement stage. The potential development of tourism in the whole area is limited by its relative unimportance in terms of employment (q3) in many parts of the area (compare Martin \& Uysal, 1990) on different thresholds in different life cycle stages). The tourism industry has recorded some growth, but despite some consensus on possible policy strategy (q4), it is only when tourism gains momentum in size and share within the regional economy, that a more concerted and effective policy and entrepreneurial effort can take place.

\section{Acknowledgements}

We thank the Raad voor de Wadden for providing financial support for the research (sections 3 and 4). VVV Terschelling and Jan Pieter Kok have kindly given support for the research on the historical development of Terschelling (section 2). And finally, we are grateful to professional corrector and native speaker Susan Davis for correcting the English. This publication is part of the activities performed within the frame-work of the 'Wadden Sea

${ }^{17}[32]$, p. $48:$ '... decline is an ongoing threat ... restructuring is a continuous process...' 
Long-term Monitoring Ecosystem Research (WaLTER)' project, which is funded by the Dutch Waddenfonds and by the Provinces of Noord-Holland and Fryslân (www.walterproject.nl and www.walterwaddenmonitor.org).

\section{References}

Agarwal, S. (1997) The resort cycle and seaside tourism: An assessment of its applicability $\begin{array}{lllll}\text { and } \quad \text { Talidity, } & \text { Tourism } & \text { 65-73. }\end{array}$ http://dx.doi.org/10.1016/S0261-5177(96)00102-1

Baum, T. (1998). Taking the Exit Route: Extending the Tourism Area Lifecycle Model. Current Issues in Tourism, 1, 167-175. http://dx.doi.org/10.1080/13683509808667837

Brewer, J., \& Hunter, A. (2006). Foundations of multi-method research - synthesizing styles. Thousand Oaks: Sage.

Butler, R. W. (1980). The concept of a tourist cycle of evolution: implications for management and resources. The Canadian Geographer, 24, 5-12. Republished in Butler 2006a p. 3-12. http://dx.doi.org/10.1111/j.1541-0064.1980.tb00970.x

Butler, R. W. (1999). Sustainable tourism: A state - of - the - art review. Tourism Geographies: An International Journal of Tourism Space, Place and Environment, 1(1), 7-25. http://dx.doi.org/10.1080/14616689908721291

Butler, R. W. (ed) (2006a). The tourism area life cycle. Vol. 1: Applications and modifications. Clevedon: Channel View.

Butler, R. W. (ed) (2006b). The tourism area life cycle. Vol. 2: Conceptual and theoretical issues. Clevedon: Channel View.

Claver-Cortés, E., Molina-Azorín, J. F., \& Pereira-Moliner, J. (2007). Competitiveness in mass tourism, Annals of Tourism Research 34, 727-745. http://dx.doi.org/10.1016/j.annals.2007.03.010

Daams, M.N. \& Sijtsma, F.J. (2013). Planting the SEED: Towards a spatial economic ecological database for a shared understanding of the Dutch Wadden area. Journal of Sea Research, 82, 153-164. http://dx.doi.org/10.1016/j.seares.2012.12.002

De Jong, F (2007). Wadden sea and climate change. Naturschutz und Landschaftsplanung. 39, 253-254.

De Vries, S., Buijs, A., Langers, F., Farjon, H., Van Hinsberg, A., Sijtsma, F. J. (2013). Measuring the attractiveness of Dutch landscapes: identifying national hotspots using Google Maps. Applied Geography, 45(12), 220-229 http,//dx.doi.org/10.1016/j.apgeog.2013.09.017

Deskins, J. \& Seevers, M. T. (2011). Are state expenditures to promote tourism effective? Journal of Travel Research, 50(2), 154-170. http,//dx.doi.org/10.1177/0047287510362785

Dissart, J. \& Vollet, D. (2011). Landscapes and territory-specific economic bases. Land Use Policy, 28, 563-573. http,//dx.doi.org/10.1016/j.landusepol.2010.11.004 
Dodds, R., \& Ko, S. (2012).. Assessing Stakeholders' Views of Tourism Policy in Prince Edward County. Environmental Management and Sustainable Development, 1(1), p52-70. http,//dx.doi.org/10.5296/emsd.v1i1.1624

Enemark, J. (2005). The Wadden Sea protection and management scheme-towards an integrated coastal management approach? Ocean and Coastal Management, 48, 996-1015. http,//dx.doi.org/10.1016/j.ocecoaman.2005.03.009

Farrell, B. H., \& Twining-Ward, L. (2004). Reconceptualising tourism, Annals of Tourism Research, 31, 274-295. http,//dx.doi.org/10.1016/j.annals.2003.12.002

George Hughes, C. (1982). The employment and economic effects of tourism reappraised. Tourism Management, 3, 167-176. http,//dx.doi.org/10.1016/0261-5177(82)90065-6

Getz, D. (1992). Tourism planning and destination life cycle, Annals of Tourism Research, 19, 752-770. http,//dx.doi.org/10.1016/0160-7383(92)90065-W

Hall, C. M., \& Page, S. J. (2009). Progress in Tourism Management, From the geography of tourism to geographies of tourism-A review. Tourism Management, 30(1), 3-16. http,//dx.doi.org/10.1016/j.tourman.2008.05.014

Helbing, C. (1992). The national park Niedersächsisches Wattenmeer, Ocean and Coastal Management, 18, 215-219. http,//dx.doi.org/10.1016/0964-5691(92)90024-F

Hernández, J. M., \& León, C. J. (2007). The interactions between natural and physical capitals in the tourist lifecycle model. Ecological Economics, 62, 184-193. http,//dx.doi.org/10.1016/j.ecolecon.2006.06.009

Hoekstra, H. (2009). "Men meldt ons van Terschelling..." de verandering van de economisch geografische positie van Terschelling in de afgelopen 100 jaar [in Dutch. "It is reported from Terschelling, the change in the economic-geographic position of Terschelling in the last 100 years], University of Groningen, Wetenschapswinkel Economie \& Bedrijfskunde, Groningen. http,//irs.ub.rug.nl/ppn/324895216

Hovinen, G. R. (1982). Visitor cycles, Outlook for tourism in Lancaster County. Annals of Tourism Research, 9(4), 565-583. http,//dx.doi.org/10.1016/0160-7383(82)90073-1

Hovinen, G. R. (2002). Revisiting the destination lifecycle model, Annals of Tourism Research, 29, 209-230. http,//dx.doi.org/10.1016/S0160-7383(01)00036-6

Khan, M. M. (1997). Tourism development and dependency theory, mass tourism vs. ecotourism, Annals of Tourism Research, 24, 988-991. http,//dx.doi.org/10.1016/S0160-7383(97)00033-9

Libosada, Jr., C. M. (2009). Business or leisure? Economic development and resource protection-Concepts and practices in sustainable ecotourism, Ocean and Coastal Management, 52, 390-394. http,//dx.doi.org/10.1016/j.ocecoaman.2009.04.004

Martin, B. S., \& Uysal, M. (1990). An examination of the relationship between carrying 
capacity and the tourism lifecycle, Management and policy implications. Journal of Environmental Management, 31, 327-333. http,//dx.doi.org/10.1016/S0301-4797(05)80061-1

Oreja Rodríguez, J.R., Parra-López E. \& Yanes-Estévez, V. (2008). The sustainability of island destinations, Tourism area life cycle and teleological perspectives. The case of Tenerife. Tourism Management 29, 53-65. http,//dx.doi.org/10.1016/j.tourman.2007.04.007

Polo, C., Ramos, V., Rey-Maquieira, J., Tugores, M., \& Valle, E. (2008). The potential effects of a change in the distribution of tourism expenditure on employment. Tourism Economics, 14, 709-725. http,//dx.doi.org/10.5367/000000008786440210

Russell, R. \& Faulkner, B. (2004). Entrepreneurship, Chaos and the Tourism Area Lifecycle, Annals of Tourism Research 31, 556-579. http,//dx.doi.org/10.1016/j.annals.2004.01.008

Sijtsma, F. J., Werner, G. J., \& Broersma, L. (2008). Recreatie en toerisme in het Waddengebied - Toekomstige ontwikkelingsmogelijkheden en hun effecten op economie, duurzaamheid en identiteit. Analyserapport behorende bij advies Raad voor de Wadden 2008/05 [In Dutch, Recreation and tourism in the Wadden area. Future development opportunities and their impact on economics, sustainability and identity]. http,//www.raadvoordewadden.nl/fileadmin/inhoud/pdf/adviezen_ned/2008/200805_analyser apport_RenT.pdf

Sijtsma, F. J., Daams, M. N., Farjon, H., \& Buijs, A. E. (2012). Deep feelings around a shallow coast. A spatial analysis of tourism jobs and the attractivity of nature in the Dutch Waddenarea. Ocean and Coastal Management, 68, 138-148. http,//dx.doi.org/10.1016/j.ocecoaman.2012.05.018

Sijtsma, F. J., Van der Heide, C. M., \& Van Hinsberg, A. (2013). Beyond monetary measurement, How to evaluate projects and policies using the ecosystem services framework. Environmental Science and Policy, 32, 14-25. http,//dx.doi.org/10.1016/j.envsci.2012.06.016

Sijtsma, F. J., Farjon, H., Van Tol, S., Van Hinsberg, A., Van Kampen, P., \& Buijs, A. (2013). Evaluation of landscape changes - Enriching the economist's toolbox with the Hotspotindex. In, W. Heijman, \& C. M. J. v. d. Heide (Eds.), The Economic Value of Landscapes. Chapter, 8, 136-164. London, Routledge.

Statistics

Netherlands,

2014. http,//www.cbs.nl/nl-NL/menu/methoden/classificaties/overzicht/sbi/sbi-1993/default.htm [overview $=$ Standard Industrial Categorisation 1993]

Van der Aa, B. J. M., Groote, P. D., \& Huigen, P. P. P. (2004). World heritage as NIMBY? The case of the Dutch part of the Wadden Sea. Current Issues in Tourism, 7, 291-302. http,//dx.doi.org/10.1080/13683500408667986

Vera-Rebollo, F., \& Rodríguez-Sánchez, I. (2010)., Tourism strategies for the renovation of mature coastal tourist destinations in Spain. WIT Transactions on Ecology and the Environment. 139, 21-33. http,//dx.doi.org/10.2495/ST100031 


\section{Macrothink}

Environmental Management and Sustainable Development

ISSN 2164-7682

2015, Vol. 4, No. 2

Vugteveen, P., Van Katwijk, M. M., Rouwette, E., \& Hanssen, L. (2014). How to structure and prioritize information needs in support of monitoring design for Integrated Coastal $\begin{array}{llll}\text { Management. Journal } & \text { Sea } & \text { Rearch, }\end{array}$ http,//dx.doi.org/10.1016/j.seares.2013.10.013

\section{Copyright Disclaimer}

Copyright for this article is retained by the author(s), with first publication rights granted to the journal.

This is an open-access article distributed under the terms and conditions of the Creative Commons Attribution license (http://creativecommons.org/licenses/by/3.0/). 